\title{
Plant Level Evidence on Product Mix Changes in Chilean Manufacturing *
}

\author{
Lucas Navarro $^{\dagger}$
}

November 2008

\begin{abstract}
This paper analyzes changes in the product mix by Chilean manufacturing plants in the period 1996-2003. Three-quarters of the surviving plants changed the set of products produced and more than three-quarters of the exporting plants changed the mix of products they exported during the sample period. Plants that changed their product mix contributed $85 \%$ of the aggregate growth in real sales of surviving plants between 1996 and 2003. Finally and in contrast to the US evidence, there is a negative correlation between revenue per product and the number of products. Apart from this, new evidence consistent with recent models of multi-product heterogeneous firms and trade is provided.
\end{abstract}

\section{Introduction}

This paper empirically analyzes product changing activities in Chilean manufacturing. It uses a dataset for Chilean manufacturing plants including apart from information on plant characteristics

*JEL Classification: D21, E23, F14, L11, O14, O54. Keywords: heterogeneous plants, multiple products, entry and exit, trade, development.

${ }^{\dagger}$ Department of Economics, ILADES-Georgetown University/ Universidad Alberto Hurtado lunavarr@uahurtado.cl. I am grateful to Gustavo Crespi and Raimundo Soto for sharing the data used in this paper. I also thank Caroline Paunov for her comments and help on the construction of the dataset. All errors are my own. 
data on each of the plants produced and exported products for the period 1996-2003. The information comes from the Annual Industrial Survey (ENIA) carried out by the Chilean Institute of Statistics (INE) and includes data for more than 4,000 plants per year producing a total of 3,575 different products.

The paper is based on Bernard, Redding and Schott (2006a), henceforth BRS, who analyze the prevalence of product switching activity using five-year Census information for the US. BRS observe that adding and dropping products is a very common activity among US manufacturing firms and that the firms extensive margin, i.e. the change in their mix of products, explains almost two-thirds of the aggregate growth of US manufacturing real output between 1972 and 1997.

There are at least three reasons to motivate this paper: First, it is interesting to analyze how product switching takes place in an emerging open economy like Chile. ${ }^{1}$ One particular characteristic of Chilean manufacturing is its substantial heterogeneity. For example, $70 \%$ of the plants have less than 50 employees but they only contribute to $10 \%$ of total manufacturing output in the pooled 1996-2003 sample. Second, it is also necessary to consider how product mix changes take place at frequencies higher than five years like in BRS and using different product definitions. Third, even though there are a few empirical studies analyzing the extensive margins of trade and production and their relation, ${ }^{2}$ this is probably the first paper to use self contained information on the extensive and intensive margins of production and trade within a plant.

I find that $52 \%$ of the plants produce more than one product and they generate $56 \%$ of output in the pooled sample. Despite the substantial heterogeneity in plants characteristics, multiple product plants represent an important group regardless of their employment and output level, ownership structure and sector of production. The average multiple product plant is bigger in terms of output and employment and more productive than the average single product one. Results also reflect a tight link between multiple products production and exporting activity. Indeed, more than $70 \%$ of multi-product plants output is contributed by plants that reported some exporting activity. I find that multiple products production strengthens the productivity advantages of exporters

\footnotetext{
${ }^{1}$ Bernard, Redding and Schott (2006c) highlight the problems in obtaining new available firm-product data.

${ }^{2}$ See for example Bernard, Jensen, Redding and Schott (2007).
} 
documented by the empirical literature. ${ }^{3}$

It is also presented new evidence on the links between production and international trade in heterogeneous firms. Consistent with new models of industry dynamics and trade like Bernard, Redding and Schott (2006b) and Eckel and Neary (2006), the data on number of products per plant suggest that multiple product plants shrink the number of products they produce and focus in their core competencies when becoming exporters.

Another section of the paper documents the contribution of product switching activities to aggregate growth in real manufacturing sales in Chile during the sample period. It is observed that $85 \%$ of the $35 \%$ aggregate growth in real sales by surviving plants between 1996 and 2003 is explained by the contribution of plants that changed their product mix. These results stress the extreme importance of product switching activities for aggregate output growth in Chilean Manufacturing and confirm the relevance of innovation for industry performance.

In line with the above, product switching is a very common activity in ENIA plants. One-third of the surviving plants change their product mix every year and three-quarters of them changed it between 1996 and 2003. There is indeed a frequent adding and dropping of products not only in the plants' productive structure but also in their presence in international markets. More than three-quarters of the exporters, single and multiple product ones, changed the mix of products they exported in the 1996-2003 period. Interestingly, almost all of the changes in the extensive margin of international trade involve changes in the extensive margin of production. Results of different empirical tests described in the paper also indicate that these changes in plants products mix are associated to plants performance and that they are consistent with the firm-product specific explanations of product switching proposed by BRS.

Finally it is observed a negative correlation between the intensive and the extensive margins of output and exports. That is, revenue per product and exports per product are decreasing in the number of produced and exported products, respectively. This is exactly the opposite to what Bernard, Redding and Schott (2006b) find in another study using data for the US. On the other

\footnotetext{
${ }^{3}$ Alvarez and Lopez (2005) analyze the superior characteristics of exporters relative to non-exporters in Chilean manufacturing.
} 
hand, the finding that total revenue and exports increase with the corresponding extensive margins indicate that plants gain by adding new products but that gain reduces revenues per product. These results can be explained by the existence of diseconomies of scope in Chilean manufacturing plants.

The rest of the paper is structured as follows: Section 2 describes the dataset and presents some facts about multiple product and exporting plants in the sample. Section 3 documents the contribution of product switching to aggregate sales growth and analyzes the prevalence and impact of product switching activities. Section 4 investigates why plants switch products in line of recent theories. The conclusions and an appendix including some additional information are presented in Sections 5 and 6 , respectively.

\section{Dataset}

This paper uses data from the national annual manufacturing survey (Encuesta Nacional Industrial Anual, ENIA) managed by the official Chilean statistics agency (Instituto Nacional de Estadísticas, INE). The unit of observation is a plant with ten or more employees and there are more than 4,000 plants per year in the sample. The dataset contains information for almost 35,000 plants from 1996 to 2003 . There are many studies that have used this plant level dataset for many purposes. Recent examples are Pavcnik (2002) and Levinsohn and Petrin (2003). All the studies using the ENIA dataset focus on plants characteristics. This study also considers the different products Chilean manufacturing plants produce and export. Indeed, I add to the plant level information the disaggregation of quantities produced, sold and exported, and the value of sales and exports for the different plant products. ${ }^{4}$ It should be noted that more than $95 \%$ of the plants produce for single-plant firms in 1996, the only year with firm and plant level information available. ${ }^{5}$

The definition of a product is specific to the dataset. Given the information available it can only

\footnotetext{
${ }^{4}$ The data on the value of exports by product is only available until 2000. Data on quantities exported are available for all the years in the sample.

${ }^{5}$ There were a number of problems arising in the processing of the data. Like in pevious studies that use the ENIA survey there were removed plants with internal inconsistencies in the information.
} 
be said that it is more disaggregated than a seven-digit Second Revision International Standard Industry Classification (ISIC). Hereafter I will refer to the more disaggregated definition of a product as "product" or "ENIA product". It is possible to assign the products to different seven-digit and more aggregate ISIC categories. I will refer to two-digit ISIC categories as "sectors" and four-digit ISIC categories as "industries". At different stages of the study I will also use five-digit and sevendigit ISIC categories. Table 1 reports the information on the number of industries, five-digit ISIC products, ENIA products and exported products by sector. There are ten sectors, 95 industries, 264 five-digit ISIC categories, 2,141 seven-digit ISIC categories and 3,575 ENIA products. About 41\% of the products were exported at least one year by at least one plant in the sample. As observed in the table, the distribution of products by sector is highly heterogeneous. The number of products by sector ranges from 121 to the 1,296 products produced in the Fabricated Metal Products, Machinery and Equipment sector. The information on capital intensity and skill intensity by product as defined in BRS also shows substantial variation within and across sectors. ${ }^{6}$

One remarkable feature of Chilean manufacturing well documented in numerous studies and confirmed in this paper is its substantial heterogeneity. The first three columns of Table 2 report the percent of plants, real output and exporter plants across employment and ownership categories. ${ }^{7}$ The table shows that almost $70 \%$ of the plants in the dataset employ less than 50 employees, they only contribute to $10 \%$ of total output and $8 \%$ of them are exporters. On the other extreme $8 \%$ of the plants have more than 200 employees, they generate $65 \%$ of manufacturing output in the pooled 1996-2003 sample and $73 \%$ of them export at least one of their products.

The distribution of plant and output by ownership also displays some peculiar characteristics. $94 \%$ of the plants are private domestic and they produce $62 \%$ of total output. The remaining $6 \%$

\footnotetext{
${ }^{6}$ This information is reported in the Appendix.

${ }^{7}$ Real values were obtained using plant level prices based on the information on value and quantities of sales for each product per plant. They were calculated using the methodology of Eslava, Haltiwanger, Kugler and Kugler (2004). Then, to construct plant level prices there were ignored plants with average price changes greater than 50 percentage points per year and also plants with discontinuous information over time. To avoid price changes associated to changes in plants product mix there were also ignored plants which significantly changed their mix of products during the sample years. At the end of this procedure, plants with missing price information were assigned the average price for the industry in which they produce.
} 
of the plants have some foreign capital or state ownership and they produce the remaining $38 \%$ of total output. Also, while $19 \%$ of the private domestic plants are exporters, almost $65 \%$ of the plants with some foreign capital ownership export their products.

The sectorial level information presents a similar pattern. For example, the Basic Metal Industries sector, which includes copper and mining industries, is represented by less than $2 \%$ of the plants in the sample and contributes to more than $23 \%$ of total output with $44 \%$ of its plants exporting. On the other hand, almost $15 \%$ of the plants produce in the Textile sector but they only represent less than $4 \%$ of total manufacturing output and $18 \%$ of its plants export their products. ${ }^{8}$

This substantial heterogeneity reported in the above mentioned dimensions is not translated into a substantial heterogeneity in the prevalence of multiple product plants in Chilean manufacturing. Column four of Table 2 reports the percent of plants that produce more than one product. It indicates that there are $52 \%$ of multiple product plants in the pooled 1996-2003 sample. As it will be discussed later these group of plants contribute to $56 \%$ of total output in manufacturing. Multiproduct plants represent an important group no matter the employment level, ownership structure and the sector in which the plants produce. Indeed, the percent of multiple product plants ranges from 48 to $65 \%$ across employment size categories, from 30 to $52 \%$ by ownership and from 42 to $59 \%$ across sectors.

The last column of Table 2 displays the percent of plants that produce multiple products and export at least one product. It shows that $12 \%$ percent of the plants are multi-product and exporters. This implies that $57 \%$ of the exporting plants produce multiple products and that $23 \%$ of multiple product plants are exporters. These numbers can be compared with the respective $52 \%$ and $21 \%$ of multi-product and exporter plants in the overall sample. This pattern of over representation of multiple product plants among exporters and of exporters among multiple product plants is present in high employment, private domestic and foreign plants in almost all the sectors. 9

Table 3 explores in more detail the observed relation between multiple products production

\footnotetext{
${ }^{8}$ The disaggregation of Table 2 by sector is presented in the Appendix.

${ }^{9}$ Although BRS do not report the corresponding information these results are in line with their finding that the probability of exporting is higher for multiple product firms in the US.
} 
and exporting activities. The first column breaks down plants in four groups: single product and non-exporters, single product and exporters, multi-product non-exporters and multi-product and exporters. The next three columns report respectively the percent of plants, output and exports for each group.

As mentioned before $52 \%$ of the plants produce multiple products and contribute to a similar $56 \%$ of total real output in manufacturing. ${ }^{10}$ Interestingly, more than $70 \%$ of the multi-product plants output (equivalent to $40 \%$ of total manufacturing output) is generated by the $12 \%$ of multiple product plants that have reported some exporting activity. This group of plants contribute to $58 \%$ of total exports in the pooled 1996-2000 sample. ${ }^{11}$ In a similar way, it can be noted in the table that exporters also represent a reduced group of plants that dominate production among single product plants.

Finally, the last two columns of Table 3 report the average number of produced and exported products per plant. The average multi-product plant produces nearly four products per year. The table shows that multi-product exporters introduce a subset of their products in international markets. It is interesting to note that multi-product plants that only operate in the domestic market produce on average more products than their multi-product competitors with international presence. ${ }^{12}$ This result is consistent with a theoretical model by Bernard, Redding and Scott (2006b) in which the opening of trade leads multi-product firms to drop low-productivity products and focus on their core competencies. In a similar way this result is also consistent with Eckel and Neary (2006).

The identification of multiple product plants has not yet considered the degree of differentiation among the products produced by a plant. It can be thought that the cost of introducing a new product differs according to how the new product characteristics compare to the current products ones. It would be then easier for the plant to offer products of the same industry or sector rather

\footnotetext{
${ }^{10}$ These results are quite different from those reported for the US by BRS. Using five-year census data and a different product definition they find that $41 \%$ of the firms produce more than one product and they account for $91 \%$ of output in US manufacturing in a pooled 1972-1997 sample.

${ }^{11}$ Information on the value of exports by product for 2001-2003 was not available.

${ }^{12} \mathrm{~A}$ simple difference in means test confirms that this result is statistical significant at $1 \%$ level.
} 
than of different ones. Table 4 gives an idea of the production diversification efforts by Chilean manufacturing plants. It presents a classification of plants according to the product dimension in which they operate. It considers not only single and multi-product plants but also plants producing in different five-digit ISIC groups, industries and sectors. Columns two, three and four show the percent of plants, real output and average number of products in each category. As can be noted, the fraction of plants and output and the number of products per plant represented by each group is clearly decreasing in the degree of aggregation of the product classification. While $36 \%$ of the plants produce more than one five-digit ISIC products, only $9 \%$ of them produce in more than one two-digit ISIC categories (sectors).

I also find that the distribution of sales across products is highly skewed. The data presented in Table 5 shows that the average sale of the top plant's product declines from 81 to $41 \%$ as the number of products goes from 2 to 10. The distribution of exports across exported products (bottom panel Table 5) displays a similar trend. The results indicate that plants have a dominant produced and exported product and that their relative importance decreases with the number of produced and exported products, respectively. These results are comparable to what BRS find for the US.

Table 6 provides more information on the characteristics of multiple product and exporting plants in the pooled 1996-2003 sample. Each cell shows the coefficient of a separate regression of the log of the plant characteristic on a dummy variable for multiple product, single product exporters and multiple product and exporting plants, respectively. All regressions are OLS except for the probability of export which is a probit and they all include year and industry fixed effects. Standard errors (not reported) were obtained controlling for clustering at the industry level. Except for wages and labor productivity in column two, all the coefficients are statistical significant at the $1 \%$ level.

Results of column two indicate that compared with single product plants, multiple product plants are on average $26.4 \%$ and $26.2 \%$ bigger in terms of output and employment, respectively, and they display a $26 \%$ higher average total factor productivity, hereafter TFP. ${ }^{13}$ Also, in line with

\footnotetext{
${ }^{13} \mathrm{TFP}$ was caculated like in BRS using the multi-factor superlative index number of Caves, Christensen and Diewert (1982). It was obtained an index number for the percentage difference in plant productivity from the mean of all plants in the same industry for each year.
} 
the results of Tables 2 and 3, the probability of export is higher among multi-product plants.

The results of the last two columns are consistent with the empirical evidence on the characteristics of exporters in Chile. ${ }^{14}$ That is, exporters are bigger, more productive and pay higher wages than non exporting plants. A new result arising from Table 6 is that those characteristics are strengthened when exporters produce multiple products. As indicated in the table all but one of the reported coefficients of column four are bigger than the corresponding ones of column three.

\section{Product Switching}

\subsection{Product Switching and Aggregate Sales Growth}

BRS propose the following decomposition of the aggregate change in output or in the case of this study sales, $\Delta Y_{t}$, as

$$
\Delta Y_{t}=\sum_{j \in N} \Delta Y_{j t}+\sum_{j \in X} \Delta Y_{j t}+\sum_{j \in C}\left[\sum_{i \in G} \Delta Y_{i j t}+\sum_{i \in S} \Delta Y_{i j t}+\sum_{i \in A} \Delta Y_{i j t}+\sum_{i \in D} \Delta Y_{i j t}\right] .
$$

The first two terms account for the contribution of plant entry $(N)$ and exit $(X)$ and the remaining four ones account for the contribution of continuing plants $(C)$. The third and fourth terms consider the contribution of growing $(G)$ and shrinking $(S)$ plants' existing products, the intensive margin. The last two terms represent the extensive margin of the change in total sales, that is the change due to the adding $(A)$ and dropping $(D)$ of products by continuing plants. In the expression above $j$ denotes plants and $i$ denotes products. Table 7 presents the decomposition of the aggregate change in sales in Chilean manufacturing from 1996 to 2003 and in three sub periods.

Column two reports the total growth in real manufacturing sales. Columns three to five report the contribution of net plant entry, gross plant entry and gross plant exit, respectively. Column six displays the contribution of continuing plants. Columns seven to nine present the net and gross contribution of the intensive margin, and columns ten to twelve the corresponding ones for the extensive margin. Note that the sum of the net extensive and intensive margins is equal to the

\footnotetext{
${ }^{14}$ See for example Alvarez and Lopez (2005).
} 
growth of continuing plants sales. Also, total sales growth is equal to the growth in sales due to net entry plus the total growth of sales in continuing plants.

As indicated in the last row of the table sales increased by more than $43 \%$ from 1996 to 2003 . This resulted from an $8 \%$ due to the net entry of plants plus more than $35 \%$ due to the growth of continuing plants. This growth by continuing plants is explained by $16 \%$ due to the intensive margin and more than $19 \%$ represented by the net entry of surviving plants products. Therefore the plants' extensive margin explains more than $44 \%$ of total manufacturing sales growth in the entire sample period. Data for the other periods also display positive growth in total sales with substantial variation across time in the contribution of net entry, the intensive and the extensive margins. The gross contributions associated to the extensive and intensive margins indicate a moderate level of excess reallocation in the 1996-2003 period which is much lower than the one associated to the entry and exit of plants in the sample. ${ }^{15}$

Table 8 presents an alternative decomposition of sales growth according to whether plants did or did not change their product mix between two periods. The table decomposes the growth in real sales of continuing plants in four components:

$$
\sum_{j \in C} \Delta Y_{j t}=\sum_{j \in U} \Delta Y_{j t}+\sum_{j \in M} \Delta Y_{j t}+\sum_{j \in L} \Delta Y_{j t}+\sum_{j \in E} \Delta Y_{j t}
$$

The first term denotes the contribution to growth in real sales by plants that did not change their product mix $(U)$. The remaining ones consider the contribution of plants that changed their product mix and as a result either produce more $(M)$, less $(L)$ or an equal number of products $(E)$. Column two reports the total growth of sales of continuing plants. Columns three and four account for the contribution to sales growth of the plants that did not and did alter their ENIA product mix, respectively. Columns five to seven disaggregate the magnitudes of column four into plants that increased, decreased or did not change the number of product lines. Note that columns five to seven add up to the values of column four.

Results confirm the importance of product switching for the aggregate growth in real sales in Chilean manufacturing. Indeed, growth in sales of surviving plants seems to be closely associated

\footnotetext{
${ }^{15}$ The evidence for the US on this point is somewhat different. BRS find a significant degree of excess reallocation in both the extensive and intensive margins.
} 
to changes in their product mix in all the four periods considered. The last row of the table shows that $85 \%$ of the growth in sales of continuing plants between 1996 and 2003 is explained by the contribution of plants that changed their product mix by either altering their number of product lines or leaving it unchanged. Interestingly, the table shows that even decreasing the number of product lines can lead to gains in plants sales.

\subsection{Prevalence of Product Switching}

The bottom line of the previous analysis is that product switching is an important determinant of growth in total sales in Chilean Manufacturing. This subsection investigates in what extent do plants switch products. Following BRS there are four possible mutually exclusive actions of a plant between two periods regarding its product mix: No changes, drop products only, add products only or both add and drop products.

Table 9 reports the average annual and total product switching activity by surviving plants in the period 1996-2003. It presents information for single product and multiple product plants. The bottom panel of the table shows the same information weighted by plant sales share.

The table indicates that while on average only $32 \%$ of the surviving plants did some product switching activity between two consecutive years, three-quarters of the surviving plants changed their product mix in some way between 1996 and 2003.

The other result that comes up from the table is that product switching is more prevalent among multiple product than single product plants. Indeed, 93\% of multiple product plants survivors introduced changes in their set of products between 1996 and 2003 and an average $48 \%$ of those plants altered their product mix every year. Among single product plants, $15 \%$ and $47 \%$ of them added or churned products between two consecutive years and in the whole sample period, respectively.

As can be noted, the data on prevalence of product switching weighted by plant sales is remarkable similar to the unweighted data. This suggests an even distribution of product switching activities across plant sizes. This is particularly interesting considering that as Table 2 shows nearly 
$70 \%$ of the plants in the sample represent $10 \%$ of total manufacturing output. ${ }^{16}$ Product switching activities are not exclusive to large plants but to all the plants in the sample including the small ones. Indeed, the data of Table 9 calculated including only plants with less than 50 employees showed very similar results.

\subsection{Product Switching and Exports}

We know from the above that product switching activities are very common among surviving plants. A related question is in what extent plants add and drop exported products and how those changes affect the set of products they produce. Table 10 shows information on product switching activities by survivors considering not only their number of products but also their export orientation. Column one breaks down plants according to four categories in which a plant could be in 2003: single product non-exporter, single product and exporter, multi-product and nonexporter and multi-product and exporter. The next two columns report the fraction of plants that implemented any change in their product mix and both added and dropped products between 1996 and 2003. The difference between columns two and three represents of course the fraction of plants that either added or dropped products between the two years. Columns four and five report the same information but regarding the addition and removal of products for export (exported). The last two columns present the fraction of plants that changed their exported product mix without changing their produced product mix. They consider for example the case of a plant that stops exporting a product but continues its production for the domestic market.

The table shows that $54 \%$ of single product non-exporters did change their product mix in at least one way between 1996 and 2003, that 8\% dropped their unique exported product (column four) and that $2 \%$ continued producing a product that was exported in 1996 but not in 2003 . The data show that product switching activities are very important among both single and multiproduct exporters. Indeed, $74 \%$ of single product exporters did change their product mix and $77 \%$ of them changed their set of exported products between the two years. This pattern is even more

\footnotetext{
${ }^{16}$ These results are in general similar to those obtained by BRS for the US. They do find though evidence of more likely product switching activities for larger firms.
} 
pronounced among multi-product plants that exported at least one of their products in 2003. It can be noted in the table that an insignificant fraction of the exporters changed their set of exported products without changing their mix of produced products (last two columns). This means that almost all the changes in the extensive margin of international trade involve changes in the extensive margin of production. Finally, note that most of the changes in the set of exported products were done by both adding and dropping products.

\subsection{Product Switching and Changes in Plant Characteristics}

Table 11 reports the results of regressions of annual log differences in plants characteristics on dummies for the three alternative product switching activities. All regressions are OLS except for the probability of export which is a probit and they all include year and industry effects. The last two columns of the table report the number of observations and R-squared for each regression. Results suggest with $1 \%$ statistical significance that output falls in plants that only drop products and it increases in plants that only add products. Output seems to increase in plants that simultaneously add and drop products, but the coefficient is statistically significant only at the $10 \%$ level. There is not clear evidence of a relation between product switching activities and changes in total assets and total employment. There is though statistical significant evidence indicating that consumption of intermediate goods increases when plants add and churn products. The effect of product switching on labor productivity is consistent with the mentioned effects on output and employment. Labor productivity tends to decrease in plants that only drop products and to increase in plants that only add products. At a $5 \%$ confidence level, current TFP falls on average in plants that drop products between two years, but next year TFP increases. Also, while current TFP does not change with product churning, next year TFP is higher. Finally, results also indicate that adding and churning products are associated to a higher probability of exporting products.

This evidence suggests that it takes time for changes in the plants' product mix to have a positive impact on TFP. Even though switching products is not related to important changes in inputs apart from materials, there seem to be adjustment costs associated to product switching 
that delay its positive effects on TFP.

\section{Product Switching Explanations}

The alternative but not necessarily mutually exclusive explanations for product switching can be classified in product-specific, firm-specific and firm-product-specific.

i. Product-specific explanations are related to the existence of demand and supply shocks affecting products. This implies that at any point in time some products would be added and other different products would be dropped, and then the correlation between products adding and dropping rates should be negative. BRS define a product's add rate as the number of firms adding that product over the average total number of firms producing it between two periods of time. A similar definition applies for a product's drop rate. Using the Chilean data I find a correlation of 0.69 between the average drop and add rates over the period 1997 and 2002. ${ }^{17}$ In line with the finding of BRS for the US, product-specific explanations of product switching do not seem to be important in Chilean manufacturing.

ii. Firm-specific explanations consider that firms can add or drop marginal products as a result of productivity shocks at the level of the firm. This explanation may not seem to be consistent with the fact that the majority of product switching between 1996 and 2003 occurred by the simultaneous adding and dropping of products as reported in Table 9 (Total 1996-2003). However, the information on annual product switching activity of Table 9 (Average 1996-2003) conveys a different message. It is observed that almost half of the $32 \%$ of plants changing their product mix between years either add or drop products but not both at the time. As opposed to what BRS find for the US the new annual data for Chile suggests that we cannot completely disregard the firm-specific explanations of product switching.

iii. Firm-product-specific explanations rely on the idea that firms shocks may have different effects across products and that products shocks might have different effects across firms. ${ }^{18}$ This

\footnotetext{
${ }^{17}$ The same correlation obtained using a five-digit ISIC definition of a product is 0.86 . All correlations are significant at the $1 \%$ level.

${ }^{18}$ Klette and Kortum (2004) study the impact of innovation on the firm's number of products. Rossi-Hansberg and
} 
explanation would extend the two previous ones to allow asymmetric effects of firms and products shocks on products and firms dimensions. This seems to be consistent with the observed positive correlation between products' add and drop rates mentioned above. As it will be seen, the data for Chilean manufacturing plants seem to support this hypothesis of product switching.

A way to rationalize this explanation proposed by BRS is by extending the theories of firm entry and exit to consider product entry and exit within surviving firms. Models of industry dynamics of heterogeneous firms like the ones by Jovanovic (1982) and more recently Melitz (2003) consider that firms must pay sunk entry costs and that an unknown value of firm productivity is realized upon entry. If the firm productivity value is above a threshold the firm does produce, otherwise it endogenously exits the market. ${ }^{19}$ A model of product-firm dynamics would then have surviving firms paying up-front costs to produce a product. Thereafter firms would realize an ex-post product productivity value that compared with a threshold value would determine product entry and exit decisions. In some extent this idea is exploited in a related paper by Bernard, Redding and Schott (2006b). They develop a theory of industry dynamics with heterogeneous multi-product firms where firm-level ability and firm-product level expertise determine the firm productivity in a given product. Their model is an extension of Melitz (2003) to account for the production of multiple products.

As mentioned by BRS, in a similar way that single product firm models suggest that firm productivity is positively correlated with firm age and output, products' productivity would be positively correlated with product age and size. To the extent that a product exit is related to its productivity firms would decide to stop producing recently introduced and low output products. The same would be expected for product adding decisions if the steady state number of products is kept constant. This product switching activities are performed by surviving firms, that is those which productivity did not fall below the exit threshold. It follows that product switching activities are expected to be positively correlated with firms' productivity, and other determinants that are Wright (2006) analyze how a product shock can have uneven effects across firms. Skill biased technological change would lead to a change in the skill requirements for the production of a good, that given a skill intensity distribution across firms would lead skill-abundant firms to add the good and skill-scarce ones to drop it.

${ }^{19}$ Hoppenhayn (1992) models the case where firm productivity is hit by shocks that can lead to endogenous exit. 
positively associated to firms' productivity like output and age.

Table 12 presents the results of OLS regressions of dummy variables for product entry and exit on product and plants characteristics. The product characteristics considered are product sales and for how long has been the plant producing a product (product age). Plant characteristics include plants sales, years in the sample, number of products, labor productivity and TFP. Like in BRS, product size and tenure are measured relative to the average size and tenure of the product across plants in a year. Similarly, plant size, plant age and productivity variables are calculated relative to the average for plants producing the same product mix in a given year.

All regressions use annual data on product exit and entry for surviving plants. As indicated in the table all the coefficients are statistical significant at the $1 \%$ level. Column one reports the results for a regression of a dummy for dropped products between two consecutive years on product size, tenure, and plant size, plant tenure and number of products. As expected, it indicates that while the probability of dropping a product is decreasing in the product size and tenure, bigger plants with long tenure that produce many goods are more likely to drop products. Column two shows that this result is robust to the inclusion of five-digit products fixed effects which control for unobserved product characteristics.

Columns four and five show the results of similar regressions with the difference that they use a dummy for product entry as a dependent variable and a measure of expected life of added products, i.e. for how long the plant's added product is produced after it is introduced. Results are very similar to the ones of columns one and two. They indicate that bigger and older multiproduct plants are more likely to add products. Also, added products are relatively small and short-lived. ${ }^{20}$ These results are similar to the obtained by BRS for the US and they seem to be consistent with a product-plant explanation of product switching in Chilean manufacturing.

As an extension to the above, it can be expected that ex-ante more productive firms are more likely to add new products. This is exactly what the last two columns of Table 12 show. They present the results of two regressions of product entry on product characteristics and one period lagged relative productivity measures. As indicated, among plants producing the same mix of

\footnotetext{
${ }^{20}$ Identical probit regressions were also estimated and results were qualitatively the same like those of Table 11.
} 
products more productive plants are more likely to add new products.

Table 13 provides more evidence on the relation between product switching and productivity restricting the analysis to single product plants under different product definitions. The first two rows show results of OLS regressions of a dummy for product entry on ex-ante TFP and labor productivity respectively. All regressions include year and seven-digit ISIC fixed effects to control for unobserved products characteristics. Results do not indicate any relation between product adding and productivity. This situation changes when considering additions in different product categories. The remaining rows present the results of similar regressions considering product adding in different product spaces. They show that ex-ante productivity is higher for single-five-digit ISIC and single-industry plants adding a product in a different five-digit ISIC category and industry, respectively. Potentially, adding a product in a different five-digit category or industry might be associated to flexible production technologies available in more productive plants.

\subsection{Extensive-Intensive Margin Correlation and Theoretical Implications}

Bernard, Redding and Schott (2006b) motivate their theoretical model by providing evidence on the relation between the extensive and the intensive margin of exports and output for US manufacturing. They refer to the extensive margin as the number of produced or exported products and to the intensive margin as sales or exports per product. They find a positive correlation between the firms' intensive and extensive margins. That is, larger firms produce or export more products and also display higher output or exports per product than smaller firms. The intuition for their results is provided in their model where they assume that firm's ability and product expertise determine the productivity of a firm's product. If follows that higher ability firms produce more products because their higher ability across all their product lines compensates them for potential low ex-

pertise in their particular products. The result that larger firms also exhibit higher output per product is explained by the higher productivity and the associated lower prices charged by higher ability firms.

Nocke and Yeaple (2006) develop a theory of multiproduct firms where a higher number of product lines decreases managerial capabilities and so increases the marginal cost of each product 
line. Firms with greater organizational capability produce a larger number of product lines but they are less productive than firms with lower organizational capability. Their model predicts a negative firms' extensive-intensive margins correlation and a negative correlation between the firms' extensive margin and their productivity.

It seems interesting to investigate the relation between the extensive and the intensive margin for the case of multi-product plants in Chilean manufacturing. Table 14 reports the results of OLS regressions of sales per product, sales, exports per product and exports on the number of produced and exported products, correspondingly. All regressions include year and industry fixed effects and they consider multi-product plants only. For the case of the value of exports the information is only available until 2000. In contrast to the evidence for the US, the coefficients of column two and four indicate a negative correlation between the intensive and the extensive margins of production in Chilean manufacturing plants. ${ }^{21}$ That is, revenue per product and exports per product are larger in plants that produce or export fewer products. This does not mean that the extensive margin is not important for sales growth. Indeed, the coefficients of column three and five show that real revenue or exports are higher in plants that produce or export more products. ${ }^{22}$ Finally, the last four columns of the table show that total and unitary revenue and exports are higher in plants that charge lower prices for their products.

One way to explain the results of Table 14 is by the existence of scope diseconomies in Chilean plants. The data suggest that producing a marginal product reduces the productive capacity in other product lines. The negative correlation between revenue per product and the number of products together with the positive correlation of total revenue with the number of products

\footnotetext{
${ }^{21}$ This finding is robust to the use of different product definitions (two, four, five and seven-digit ISIC codes) and fixed effects.

${ }^{22}$ These last results are expected by definition of OLS. Given a number of products $n_{i}$ and output per product $\overline{y_{i}}=\frac{1}{n_{i}} \sum_{p} y_{p i}=\frac{Y_{i}}{n_{i}}$ for a plant $i$, regressions of columns two and three of Table 14 can be written as

$$
\begin{aligned}
& \ln \overline{y_{i}}=\alpha_{1}+\beta_{1} \ln n_{i}+u_{i 1} \\
& \ln Y_{i}=\alpha_{2}+\beta_{2} \ln n_{i}+u_{i 2}
\end{aligned}
$$
}

where $u_{i 1}$ and $u_{i 2}$ are stochastic errors. Given that $n_{i}=\frac{Y_{i}}{y_{i}}$ and by definition of OLS, $\beta_{2}-\beta_{1}=1$. As expected, the difference between the coefficients of columns three minus two, and five minus four are both one in Table 14 . 
suggests that total revenue increases less than proportionally with increases in the number of products.

As mentioned above, I also find that revenue per product decreases with plant level prices. ${ }^{23}$ To the extent that lower prices are associated to a higher plant's productivity, this result is consistent with the idea that more productive plants exhibit higher output and output per product. In the Chilean case, this higher productivity seems to be associated to a larger number of plants' products but not so large because that would negatively affect the intensive margin, i.e. revenue per product.

Summarizing, the evidence for Chile is not entirely consistent with neither Bernard, Redding and Schott (2006b) nor Nocke and Yeaple (2006). While the negative correlation between the plants' intensive and the extensive margins (Table 14) is only consistent with the latter study, the positive correlation between plants productivity and multiproduct production (Table 6) is only consistent with the former one. An extension of the model by Bernard, Redding and Schott (2006b) to include some sort of diseconomies of scope $^{24}$ would probably make it possible to reproduce the reported facts for Chilean manufacturing.

\section{Conclusions}

This paper investigates the frequency and effects of product switching activities by Chilean manufacturing plants at annual frequency in the period 1996-2003. If finds that product switching is a very common activity that affects plants performance and is an important determinant of aggregate manufacturing sales growth. There is also new evidence of substantial product mix changes

\footnotetext{
${ }^{23}$ Plant level prices were obtained as the mean of the prices of the different plants products weighted by their contribution to total revenue. It was noted during the calculations that most of the variation in plant level prices is due to variation in the products prices rather than variation in their shares in total revenue.

${ }^{24}$ Diseconomies of scope are introduced in different ways in the literature. Bulow, Geanaloplos and Kemperer (1985) and Dixon (1994) assume that the constant marginal cost of each product output is increasing in the output of the other firm products. Eckel and Neary (2006) develop a model of multiproduct firms where firms have a core product and can add new products via flexible manufacturing. Each product addition involves a higher marginal cost but leaves the marginal cost of the existing products unchanged. In Nocke and Yeaple (2006) the constant marginal cost of producing each unit of output increases with the number of product lines.
} 
in production and in international trade by exporting plants. Empirical tests support the productfirm specific explanations for product switching proposed by Bernard, Redding and Schott (2006a). Indeed, older and high output plants are more likely to change their product mix and they tend to add and drop short lived low output products.

It is observed that revenue per product and exports per product are decreasing in the number of produced and exported products, respectively. This contrasts to the model and the evidence for the US provided by Bernard, Redding and Schott (2006b) who find a positive correlation between the intensive and the extensive margins of production and trade. It is also found that total revenue and total exports are increasing in their corresponding extensive margins. Thus, even though the extensive margin is important for plants performance, there is a negative correlation between the intensive and the extensive margins. These results can be explained by the existence of diseconomies of scope in Chilean plants.

\section{References}

[1] Alvarez, R. and R. Lopez (2005) "Exporting and Performance: Evidence from Chilean Plants," Canadian Journal of Economics 38(4) pp 1384-1400.

[2] Bernard A., Jensen, J., Redding, S., and P. Schott (2007) "Firms in International Trade", Journal of Economic Perspectives, forthcoming.

[3] Bernard, A., Redding, S., and P. Schott (2006a) "Multi-product Firms and Product Switching", NBER Working Paper 12293.

[4] Bernard, A., Redding, S., and P. Schott (2006b) "Multi-product Firms and Trade Liberalization", NBER Working Paper 12782.

[5] Bernard, A., Redding, S., and P. Schott (2006c) "Products and Productivity", mimeograph.

[6] Bullow, J., Geanakoplos, D. and P. Kemplerer (1985) "Multimarket Oligopoly: Strategic Substitutes and Complements", The Journal of Political Economy, Vol. 93, No. 3, pp. 488-511. 
[7] Caves, D., Christensen, L. and E. Diewert (1982) "The Economic Theory of Index Numbers and the Measurement of Input, Output and Productivity", Econometrica, 50, 6, pp 1393-1414.

[8] Dixon, H. (1994) "Inefficient Diversification in Multi-Market Oligopoly with Diseconomies of Scope", Economica, New Series, Vol. 61, No. 242, pp. 213-219.

[9] Eckel C. and P. Neary (2006) "Multi-product Firms and Flexible Manufacturing in the Global Economy", CEPR Discussion Paper 5941.

[10] Eslava, M., Haltiwanger, J., Kugler, A., and M. Kugler (2004) "The effects of structural reforms on productivity and profitability enhancing reallocation: evidence from Colombia", Journal of Development Economics, 75, 2, pp 333-371.

[11] Hopenhayn, H. (1992) "Entry, Exit, and Firm Dynamics in Long Run Equilibrium", Econometrica, 60(5), pp 1127-1150.

[12] Jovanovic, B. (1982) "Selection and the Evolution of Industry." Econometrica 50, pp 649-670.

[13] Klette, T. and S. Kortum (2004) 'Innovating Firms and Aggregate Innovation', Journal of Political Economy, 112(5), pp 986-1018.

[14] Levinsohn, J and A. Petrin (2003) "Estimating Production Functions Using Inputs to Control for Unobservables", Review of Economic Studies, 70 pp 317-41.

[15] Melitz, M. (2003) "The Impact of Trade on Intra-Industry Reallocations and Aggregate Industry Productivity", Econometrica, 71, 1695-1725.

[16] Nocke V. and S. Yeaple (2006) "Globalization and Endogenous Firm Scope", NBER Working Paper 12322.

[17] Pavcnik, N (2002) "Trade Liberalization, Exit, and Productivity Improvement: Evidence from Chilean Plants," Review of Economic Studies, 69(1): 245-76.

[18] Rossi-Hansberg, E. and M. Wright (2006) "Establishment Size Dynamics in the Aggregate Economy", mimeograph. 
Table 1: Sectors, Industries and their Products

\begin{tabular}{|c|c|c|c|c|c|}
\hline Sector & Industries & $\begin{array}{c}\text { Five-digit } \\
\text { ISIC Products }\end{array}$ & $\begin{array}{l}\text { Seven-digit } \\
\text { ISIC Products }\end{array}$ & ENIA Products & $\begin{array}{l}\text { Exported ENIA } \\
\text { Products }\end{array}$ \\
\hline Food, Beverages and Tobacco & 16 & 49 & 278 & 411 & 213 \\
\hline Textile, Wearing Apparel and Leather & 13 & 38 & 279 & 337 & 177 \\
\hline Wood and Wood Products & 4 & 17 & 128 & 269 & 106 \\
\hline Paper, Printing and Publishing & 5 & 11 & 79 & 177 & 73 \\
\hline Chemical,Petroleum,Coal,Rubber,Plastic & 14 & 48 & 474 & 632 & 352 \\
\hline Non-Metallic Mineral Products & 9 & 20 & 125 & 166 & 74 \\
\hline Basic Metal Industries & 4 & 15 & 96 & 166 & 67 \\
\hline Fabricated Metal Products, M\&E & 26 & 55 & 613 & 1,296 & 364 \\
\hline Other Manufacturing Industries & 4 & 11 & 69 & 121 & 33 \\
\hline Total & 95 & 264 & 2,141 & 3,575 & 1,459 \\
\hline
\end{tabular}


Table 2: Multiple Product and Exporting Plants by Employment and Ownership

\begin{tabular}{|c|c|c|c|c|c|}
\hline & Percent of Plants & Percent of Output & $\begin{array}{l}\text { Percent of } \\
\text { Exporters }\end{array}$ & $\begin{array}{l}\text { Percent of Multiple } \\
\text { Product Plants }\end{array}$ & $\begin{array}{l}\text { Percent of Multiple } \\
\text { Product Exporters }\end{array}$ \\
\hline \multicolumn{6}{|l|}{ Employees } \\
\hline-50 & 68.8 & 9.9 & 8 & 48 & 4 \\
\hline 50 to 100 & 13.9 & 8.6 & 34 & 58 & 18 \\
\hline 100 to 200 & 9.1 & 16.3 & 53 & 60 & 32 \\
\hline more than 200 & 8.2 & 65.2 & 73 & 65 & 49 \\
\hline Total & 100 & 100 & 21 & 52 & 12 \\
\hline \multicolumn{6}{|l|}{ Ownership } \\
\hline Private Domestic & 94.3 & 62.0 & 19 & 52 & 11 \\
\hline Private Foreign & 2.7 & 20.1 & 65 & 52 & 36 \\
\hline Mixed & 2.5 & 9.6 & 64 & 51 & 33 \\
\hline State Owned & 0.5 & 8.3 & 34 & 30 & 9 \\
\hline Total & 100 & 100 & 21 & 52 & 12 \\
\hline
\end{tabular}


Table 3: Multiple Product Plants and Exporting Activity

\begin{tabular}{|c|c|c|c|c|c|}
\hline Plant & Percent of Plants & $\begin{array}{c}\text { Percent of } \\
\text { Manufacturing } \\
\text { Output }\end{array}$ & $\begin{array}{l}\text { Percent of } \\
\text { Manufacturing } \\
\text { Exports }\end{array}$ & $\begin{array}{l}\text { Mean Products } \\
\text { per Plant }\end{array}$ & $\begin{array}{c}\text { Mean Exported } \\
\text { Products per Plant }\end{array}$ \\
\hline Single product and non exporter & 39 & 16 & 0 & 1 & 0 \\
\hline Single product and exporter & 9 & 28 & 42 & 1 & 1 \\
\hline Multi-product and non exporter & 40 & 16 & 0 & 4.0 & 0 \\
\hline Multi-product and exporter & 12 & 40 & 58 & 3.7 & 2.1 \\
\hline
\end{tabular}


Table 4: Multiple Product Plants and Product Spaces

\begin{tabular}{lccc}
\hline Plant & Percent of Plants & $\begin{array}{c}\text { Percent of } \\
\text { Manufacturing } \\
\text { Output }\end{array}$ & $\begin{array}{c}\text { Mean Products, } \\
\text { Industries or } \\
\text { Sectors per Plant }\end{array}$ \\
\hline Single Product & 48 & 44 & 1 \\
Multiple Product & 52 & 56 & 3.9 \\
Multiple Five-Digit ISIC Product & 36 & 42 & 2.8 \\
Multiple Industry & 22 & 23 & 2.6 \\
Multiple Sector & 9 & 8 & 2.2 \\
\hline Notes: This table presents a classification of plants according to the number of products produced \\
under different product definitions. Product refers to ENIA defined products, Industry refers to four-digit \\
ISIC classification, and Sector refers to two-digit ISIC classification. Columns two and three report the \\
percent of plants and the percent of manufacturing real output represented for each category of plants, \\
respectively. The last column reports the average number of products per plant according to each \\
product definition. Data are for the 1996-2003 pooled sample.
\end{tabular}


Table 5: Mean Distribution of Sales and Exports by Number of Products

\begin{tabular}{|c|c|c|c|c|c|c|c|c|c|c|}
\hline \multirow{2}{*}{$\begin{array}{c}\text { Rank in } \\
\text { Sales }\end{array}$} & \multicolumn{10}{|c|}{ Number of ENIA Products Produced by the Plant (1996-2003) } \\
\hline & 1 & 2 & 3 & 4 & 5 & 6 & 7 & 8 & 9 & 10 \\
\hline & 1 & 0.81 & 0.69 & 0.63 & 0.59 & 0.52 & 0.5 & 0.47 & 0.44 & 0.41 \\
\hline 2 & & 0.19 & 0.22 & 0.22 & 0.21 & 0.21 & 0.2 & 0.2 & 0.21 & 0.2 \\
\hline 3 & & & 0.08 & 0.11 & 0.11 & 0.12 & 0.12 & 0.12 & 0.12 & 0.12 \\
\hline 2 & & & & 0.05 & 0.06 & 0.07 & 0.08 & 0.08 & 0.08 & 0.09 \\
\hline 5 & & & & & 0.03 & 0.04 & 0.05 & 0.05 & 0.06 & 0.07 \\
\hline 6 & & & & & & 0.02 & 0.03 & 0.04 & 0.04 & 0.04 \\
\hline 7 & & & & & & & 0.02 & 0.02 & 0.03 & 0.03 \\
\hline$\varepsilon$ & & & & & & & & 0.01 & 0.02 & 0.02 \\
\hline c & & & & & & & & & 0.01 & 0.01 \\
\hline 10 & & & & & & & & & & 0.01 \\
\hline Plants & 14,995 & 5,863 & 3,430 & 2,421 & 1,392 & 931 & 615 & 445 & 316 & 181 \\
\hline Rank in & Num & ber of & $\overline{E N I A ~ P I}$ & roducts & Export & ed by & the Pl & $\overline{\operatorname{ant}(19}$ & $996-20$ & \\
\hline Exports & 1 & 2 & 3 & 4 & 5 & 6 & 7 & 8 & 9 & 10 \\
\hline 1 & 1 & 0.81 & 0.69 & 0.62 & 0.55 & 0.49 & 0.44 & 0.42 & 0.44 & 0.42 \\
\hline 2 & & 0.19 & 0.23 & 0.24 & 0.25 & 0.23 & 0.22 & 0.22 & 0.19 & 0.17 \\
\hline 3 & & & 0.08 & 0.1 & 0.11 & 0.14 & 0.14 & 0.13 & 0.13 & 0.14 \\
\hline 4 & & & & 0.04 & 0.07 & 0.08 & 0.1 & 0.09 & 0.09 & 0.1 \\
\hline 5 & & & & & 0.03 & 0.05 & 0.05 & 0.07 & 0.06 & 0.08 \\
\hline 6 & & & & & & 0.02 & 0.03 & 0.04 & 0.04 & 0.03 \\
\hline 7 & & & & & & & 0.02 & 0.02 & 0.03 & 0.02 \\
\hline$\varepsilon$ & & & & & & & & 0.01 & 0.02 & 0.02 \\
\hline 9 & & & & & & & & & 0.01 & 0.01 \\
\hline 10 & & & & & & & & & & 0.01 \\
\hline Plants & 2,708 & $\overline{774}$ & 278 & 160 & 90 & 56 & 31 & 24 & 14 & 6 \\
\hline $\begin{array}{l}\text { Notes: } \\
\text { exports } \\
\text { for the }\end{array}$ & -2003 & poo & . & e a & C & ts 0 & ry up & 80 & pr & $\begin{array}{l}\text { ict or } \\
\text { a are } \\
\text { boled } \\
s \text { are }\end{array}$ \\
\hline
\end{tabular}


Table 6: Multiple Product and Exporting Plants Characteristics

\begin{tabular}{|c|c|c|c|}
\hline & \multirow[b]{2}{*}{ Multiple Product } & \multicolumn{2}{|c|}{ Exporters } \\
\hline & & Single Product & Multiple Product \\
\hline Output & $0.2639^{* * *}$ & 1.1786 *** & $1.6978^{* * *}$ \\
\hline Employment & $0.262^{\star \star *}$ & $0.6398^{* * *}$ & $0.8453^{* * *}$ \\
\hline Wages & 0.0066 & $0.3323^{\star * *}$ & $0.3837^{* \star *}$ \\
\hline Labor Productivity & -0.0037 & $0.5268^{* \star *}$ & $0.5158^{* * *}$ \\
\hline TFP & $0.2614^{\star * *}$ & $1.1062^{* \star *}$ & $1.6499 * \star \star$ \\
\hline Probability of Export & $0.1041^{\star \star *}$ & & \\
\hline
\end{tabular}

Notes: Each cell shows the coefficient of a separate regression of the log of the plant characteristic on a dummy variable for multiple product, single product exporters and multiple product exporting plants, correspondingly. All regressions are OLS except for the probability of export which is a probit and they all include year and industry fixed effects. Coefficients for constant and fixed effects are not reported. The wage regressions were calculated using data for 2003 only. Data for the other regressions are from the 1996-2003 pooled sample. * ${ }^{* *}$ and ${ }^{* * *}$ indicate statistical significance at $10 \%, 5 \%$ and $1 \%$ levels, respectively. 
Table 7: Decomposition of Real Aggregate Manufacturing Sales

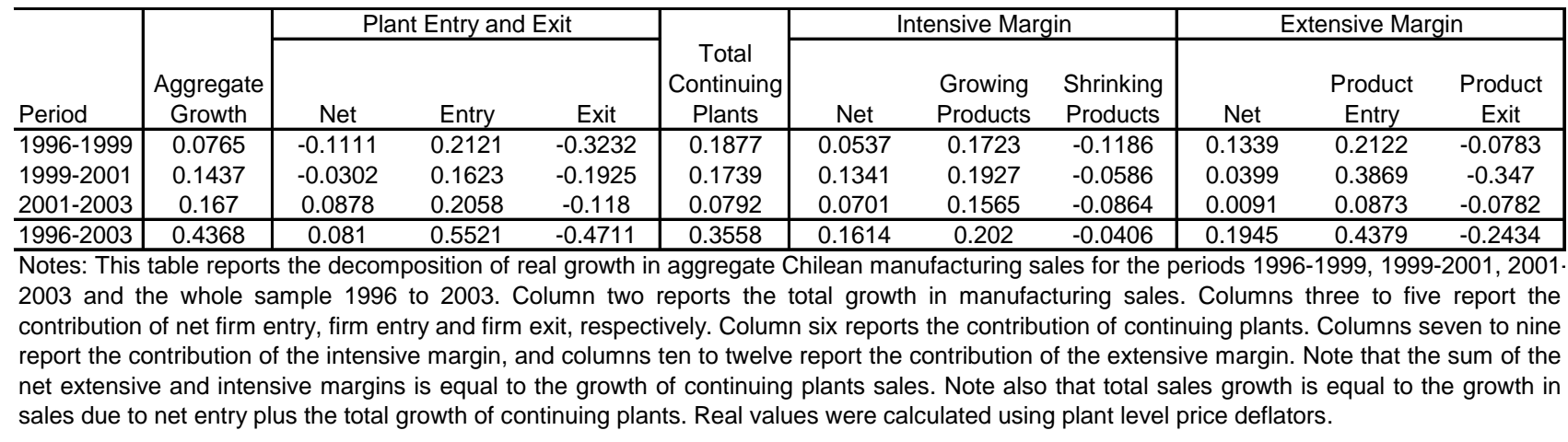


Table 8: Real Aggregate Sales of Continuing Plants and Changes in the Product Mix

\begin{tabular}{l|c|r|r|rrr|}
\hline & \multirow{2}{*}{$\begin{array}{c}\text { Total } \\
\text { Continuing }\end{array}$} & $\begin{array}{c}\text { No Change } \\
\text { in Product } \\
\text { Plants }\end{array}$ & \begin{tabular}{c} 
Change \\
\cline { 5 - 7 }
\end{tabular} & $\begin{array}{c}\text { Mroduct } \\
\text { Pix }\end{array}$ & \multicolumn{3}{|c|}{ Number of Product Lines } \\
\hline $1996-1999$ & 0.1877 & 0.0289 & 0.1588 & & & \\
$1999-2001$ & 0.1739 & 0.0474 & 0.1265 & 0.0301 & 0.0128 & 0.0162 \\
$2001-2003$ & 0.0792 & 0.043 & 0.0362 & 0.0191 & 0.0082 & 0.0543 \\
\hline $1996-2003$ & 0.3558 & 0.054 & 0.3018 & 0.1797 & 0.0809 & 0.0412 \\
\hline
\end{tabular}

Notes: This table reports the decomposition of real growth in aggregate sales of continuing plants for the periods 1996-1999, 1999-2001, 2001-2003 and the whole sample 1996 to 2003. Column two reports the total growth of sales of continuing plants. Column three reports the contribution to sales growth of the plants that did not alter their ENIA product mix. Column four reports the contribution of the plants that changed their product mix. Columns five to seven report the contribution to sales growth of the plants that increased, decreased or did not change the number of product lines, respectively. Note that columns five to seven add up to the values of column four. Real values were calculated using plant level price deflators. 
Table 9: Product Switching Activity by Surviving Plants

\begin{tabular}{|c|c|c|c|c|}
\hline \multirow[b]{2}{*}{ Share of Plants } & \multicolumn{4}{|c|}{ Plant Activity } \\
\hline & None & Drop Only & Add Only & $\begin{array}{l}\text { Both Add } \\
\text { and Drop }\end{array}$ \\
\hline \multicolumn{5}{|l|}{ Average 1996-2003 } \\
\hline Single Product & 0.85 & na & 0.05 & 0.10 \\
\hline Multiple Product & 0.52 & 0.15 & 0.08 & 0.25 \\
\hline All & 0.68 & 0.08 & 0.07 & 0.18 \\
\hline \multicolumn{5}{|l|}{ Total 1996-2003 } \\
\hline Single Product & 0.53 & na & 0.08 & 0.40 \\
\hline Multiple Product & 0.07 & 0.19 & 0.02 & 0.73 \\
\hline \multirow[t]{2}{*}{ All } & 0.25 & 0.11 & 0.05 & 0.59 \\
\hline & \multicolumn{4}{|c|}{ Plant Activity } \\
\hline $\begin{array}{l}\text { Sales Weighted } \\
\text { Share of Plants }\end{array}$ & None & Drop Only & Add Only & $\begin{array}{l}\text { Both Add } \\
\text { and Drop }\end{array}$ \\
\hline \multicolumn{5}{|l|}{ Average 1996-2003 } \\
\hline Single Product & 0.85 & na & 0.05 & 0.10 \\
\hline Multiple Product & 0.57 & 0.13 & 0.09 & 0.21 \\
\hline All & 0.71 & 0.07 & 0.07 & 0.15 \\
\hline \multicolumn{3}{|l|}{ Total 1996-2003 } & & \\
\hline Multiple Product & 0.04 & 0.17 & 0.08 & 0.71 \\
\hline All & 0.23 & 0.10 & 0.10 & 0.57 \\
\hline \multicolumn{5}{|c|}{$\begin{array}{l}\text { Notes: This table shows information about average annual and } \\
\text { total ENIA product switching activities by surviving plants over the } \\
\text { period 1996-2003. The bottom panel presents the information } \\
\text { weighted by plant sales. Between two points in time plants can } \\
\text { only drop a product, only add a product, both add and drop } \\
\text { products, or leave their product mix unchanged. }\end{array}$} \\
\hline
\end{tabular}


Table 10: Exported Products Switching Activity by Surviving Plants

\begin{tabular}{l|cc|cccc|}
\hline & \multirow{3}{*}{ All Plants Products } & \multicolumn{3}{|c|}{ Exported Products } \\
\cline { 4 - 7 } Share of Plants & Any & Both & Any & Both & Any & Both \\
\hline Single product and non exporter & 0.54 & 0.40 & 0.08 & 0 & 0.02 & 0 \\
Single product and exporter & 0.74 & 0.55 & 0.77 & 0.41 & 0.06 & 0.02 \\
Multi-product and non exporter & 0.91 & 0.76 & 0.08 & 0 & 0 & 0 \\
Multi-product and exporter & 0.94 & 0.76 & 0.90 & 0.53 & 0.02 & 0.02 \\
Total & 0.75 & 0.59 & 0.25 & 0.10 & 0.02 & 0.00 \\
\hline
\end{tabular}

Notes: This table shows information about ENIA product switching activities by surviving plants between 1996 and

2003. Column one breaks down plants according to any of the four indicated categories in which the plant was in 2003. Columns two and three report the fraction of plants in each category that did any sort of product switching activity (add only, drop only or both) and both added and dropped products, respectively. Columns four and five report the same information for changes in the mix of exported products. The last two columns report exported product switching without changes in the mix of produced products. Note that non exporter plants could have dropped exported products between 1996 and 2003. Exported product switching activities (All) involve both changes in the product mix and changes in the mix of traded products not affecting the extensive production margin (Affecting Trade Only). 
Table 11: Product Switching and Changes in Plant Characteristics

\begin{tabular}{|c|c|c|c|c|c|}
\hline & Drop Only in t & Add Only in t & Both Add and Drop in t & Observations & R-squared \\
\hline Output & $-0.0508[0.0112]^{* * *}$ & $0.0536[0.0106]^{* * *}$ & $0.0163[0.0094]^{*}$ & 23045 & 0.02 \\
\hline Employment & $-0.0058[0.0071]$ & 0.0115 [0.0078] & $0.0102[0.0053]^{*}$ & 23035 & 0.01 \\
\hline Materials & $-0.0313[0.0188]$ & $0.0644[0.0162]^{\star \star *}$ & $0.0264[0.0140]^{*}$ & 22944 & 0.02 \\
\hline Capital & $-0.0279[0.0161]^{\star}$ & $-0.0057[0.0174]$ & $0.0184[0.0142]$ & 21983 & 0.01 \\
\hline Labor Productivity & $-0.0452[0.0128]^{\star \star *}$ & $0.0415[0.0121]^{\star \star \star}$ & $0.0067[0.0084]$ & 23028 & 0.02 \\
\hline TFP & $-0.0257[0.0129]^{\star \star}$ & $0.0288[0.0132]^{\star \star}$ & $0.0003[0.0148]$ & 18162 & 0.04 \\
\hline $\operatorname{TFP}(t+1)$ & $0.0296[0.0145]^{\star *}$ & $0.0251[0.0177]$ & $0.0326[0.0166]^{\star *}$ & 14537 & 0.04 \\
\hline Probability of Export & $0.0147[0.0097]$ & $0.0292[0.0119]^{\star *}$ & $0.0314[0.0101]^{\star \star \star}$ & 23003 & \\
\hline
\end{tabular}

Notes: This table reports the results of regressions of log differences between $\mathrm{t}-1$ and $\mathrm{t}$ in plants characteristics on dummies for the three alternative contemporaneous ENIA product switching activities by surviving plants. All regressions are OLS except for the probability of export which is a probit for which the marginal effects are reported. All regressions include year and industry effects. Coefficients for constant and fixed effects are not reported. Data are for the 1996-2003 pooled plant sample. The last two columns report the number of observations and Rsquared for each regression, respectively. Standard errors adjusted for clustering at the industry level are reported in brackets next to each coefficient. ${ }^{* * *}$, and ${ }^{* * *}$ indicate statistical significance at the $10 \%, 5 \%$ and $1 \%$ levels, respectively. 
Table 12: Product Entry and Exit and Plant-Products Characteristics

\begin{tabular}{|c|c|c|c|c|c|c|}
\hline & Product Exit & Product Exit & Product Entry & Product Entry & Product Entry & Product Entry \\
\hline Relative Product Size & $\begin{array}{l}-0.0114 \\
{[0.0021]^{\star * *}}\end{array}$ & $\begin{array}{l}-0.0132 \\
{[0.0015]^{\text {***}}}\end{array}$ & $\begin{array}{l}-0.0069 \\
{[0.0021]^{\star * *}}\end{array}$ & $\begin{array}{l}-0.0071 \\
{[0.0012]^{* *}}\end{array}$ & $\begin{array}{l}-0.01 \\
{[0.0012]^{\star * *}}\end{array}$ & $\begin{array}{l}-0.0122 \\
{[0.0014]^{* * *}}\end{array}$ \\
\hline Relative Product Tenure & $\begin{array}{l}-0.0897 \\
{[0.0080]^{\star \star *}}\end{array}$ & $\begin{array}{l}-0.0917 \\
{[0.0070]^{\star * *}}\end{array}$ & & & & \\
\hline Relative Product Expected Tenure & & & $\begin{array}{l}-0.2059 \\
{[0.0135]^{\star * *}}\end{array}$ & $\begin{array}{l}-0.216 \\
{[0.0107]^{\star \star *}}\end{array}$ & $\begin{array}{l}-0.2082 \\
{[0.0125]^{\star \star *}}\end{array}$ & $\begin{array}{l}-0.225 \\
{[0.0123]^{\star \star \star}}\end{array}$ \\
\hline Relative Plant Size & $\begin{array}{l}0.0243 \\
{[0.0028]^{* * *}}\end{array}$ & $\begin{array}{l}0.0207 \\
{[0.0026]^{\star * *}}\end{array}$ & $\begin{array}{l}0.0214 \\
{[0.0026]^{* * *}}\end{array}$ & $\begin{array}{l}0.0159 \\
{[0.0029]^{\star * *}}\end{array}$ & & \\
\hline Relative Plant Age & $\begin{array}{l}0.0622 \\
{[0.0128]^{\star * *}}\end{array}$ & $\begin{array}{l}0.0575 \\
{[0.0096]^{\star * *}}\end{array}$ & $\begin{array}{l}0.0816 \\
{[0.0143]^{\star * *}}\end{array}$ & $\begin{array}{l}0.106 \\
{[0.0167]^{\star * *}}\end{array}$ & & \\
\hline Number of Products & $\begin{array}{l}0.0102 \\
{[0.0026]^{\star * *}}\end{array}$ & $\begin{array}{l}0.0095 \\
{[0.0018]^{\star * \star}}\end{array}$ & $\begin{array}{l}0.0092 \\
{[0.0021]^{\star * *}}\end{array}$ & $\begin{array}{l}0.008 \\
{[0.0015]^{\star * *}}\end{array}$ & & \\
\hline Relative Labor Productivity & & & & & $\begin{array}{l}0.0166 \\
{[0.0043]^{\star * *}}\end{array}$ & \\
\hline Relative TFP & & & & & & $\begin{array}{l}0.0227 \\
{[0.0033]^{\star * *}}\end{array}$ \\
\hline Five-digit ISIC Fixed Effects & No & Yes & No & Yes & Yes & Yes \\
\hline Observations & 60171 & 60171 & 44553 & 44553 & 44552 & 33271 \\
\hline R-squared & 0.23 & 0.28 & 0.25 & 0.31 & 0.3 & 0.31 \\
\hline
\end{tabular}


Table 13: Product Adding by Single Product Plants and Productivity

\begin{tabular}{lcccccc} 
& \multicolumn{2}{c}{ TFP } & \multicolumn{2}{c}{ Labor Productivity } & Observations & R-squared \\
\hline Add ENIA Product & 0.0059 & {$[0.0034]$} & & & 8153 & 0.39 \\
Add ENIA Product & & & 0.001 & {$[0.0051]$} & 9795 & 0.38 \\
\hline Add Five-digit ISIC Product & 0.0063 & {$[0.0017]^{* * *}$} & & & 18009 & 0.1 \\
Add Five-digit ISIC Product & & & 0.0068 & {$[0.0025]^{* * *}$} & 21432 & 0.1 \\
\hline Add Industry & 0.0044 & {$[0.0011]^{* * *}$} & & & 28846 & 0.07 \\
Add Industry & & & 0.0082 & {$[0.0017]^{* * *}$} & 34399 & 0.07 \\
\hline
\end{tabular}

Notes: This table summarizes the results of OLS regressions of dummy variables for product entry at different product dimension levels for single product plants on plant TFP and labor productivity, respectively. Row one and two consider dummies for ENIA product entry. Rows three and four consider dummies for product entry in a different five-digit ISIC category. Rows five and six consider dummies for product entry in a different industry. All regressions include year and seven-digit ISIC fixed effects. Coefficients for constant and fixed effects are not reported. Data are for the 1996-2003 pooled plantproducts sample. The last two columns report the number of observations and R-squared for each regression. Robust standard errors are reported in brackets next to each coefficient. * ${ }^{* *}$, and ${ }^{* * *}$ indicate statistical significance at the $10 \%, 5 \%$, and $1 \%$ levels, respectively. 
Table 14: Intensive and Extensive Margins OLS Regressions

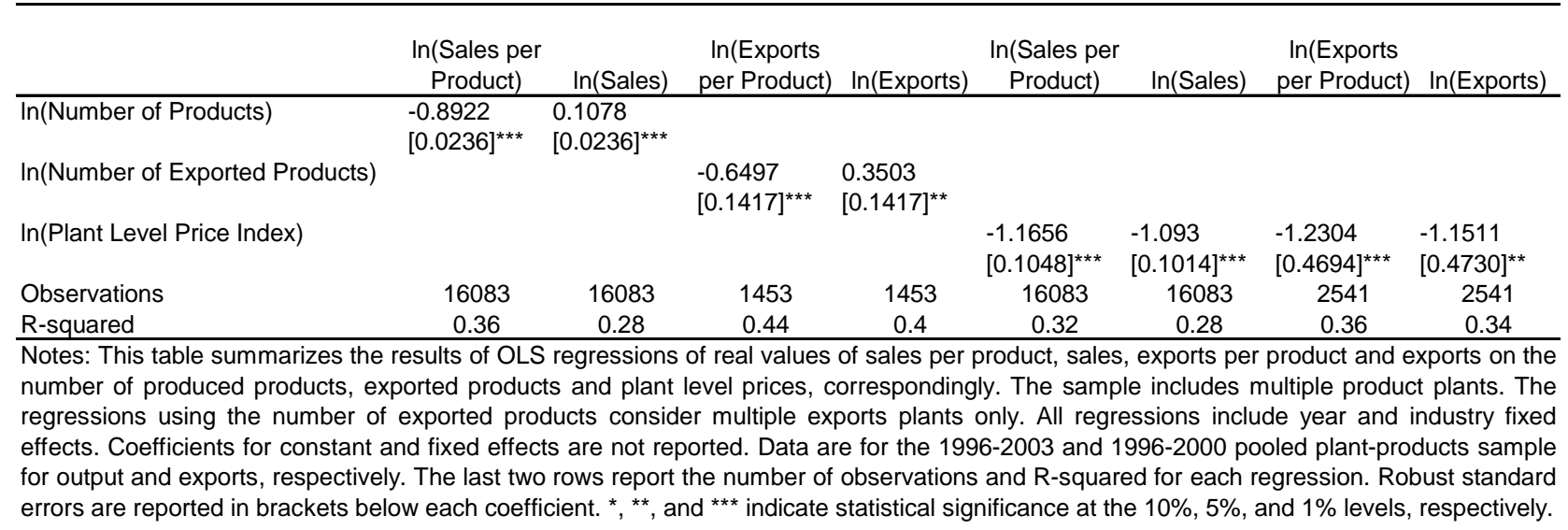




\section{Appendix}

Table A1: Products' Skill and Capital Intensity by Sector

\begin{tabular}{lcccc}
\hline & \multicolumn{2}{c}{ Skill Intensity } & \multicolumn{2}{c}{ Capital Intensity } \\
\cline { 2 - 5 } Sector & mean & $\begin{array}{c}\text { standard } \\
\text { deviation }\end{array}$ & mean & $\begin{array}{c}\text { standard } \\
\text { deviation }\end{array}$ \\
\hline Food, Beverages and Tobacco & 31 & 19 & 19 & 22 \\
Textile, Wearing Apparel and Leather & 31 & 19 & 8 & 8 \\
Wood and Wood Products & 19 & 16 & 11 & 18 \\
Paper, Printing and Publishing & 43 & 24 & 22 & 41 \\
Chemical,Petroleum,Coal,Rubber,Plastic & 35 & 21 & 55 & 158 \\
Non-Metallic Mineral Products & 30 & 18 & 33 & 47 \\
Basic Metal Industries & 42 & 27 & 55 & 95 \\
Fabricated Metal Products, M\&E & 41 & 26 & 9 & 12 \\
Other Manufacturing Industries & 42 & 27 & 8 & 9 \\
\hline Not & 42 &
\end{tabular}

Notes: Skill intensity is the average percent of production workers over total employment per plant in the pooled 1996-2003 sample. Capital intensity is the average value of fixed assets in millions of Chilean pesos per employee per plant in 2003. Means and standard deviations are computed across products. 
Table A2: Multiple Products and Exporting Plants by Sector

\begin{tabular}{|c|c|c|c|c|c|}
\hline Sector & Percent of Plants & Percent of Output & $\begin{array}{l}\text { Percent of } \\
\text { Exporters }\end{array}$ & $\begin{array}{l}\text { Percent of Multiple } \\
\text { Product Plants }\end{array}$ & $\begin{array}{l}\text { Percent of Multiple } \\
\text { Product Exporters }\end{array}$ \\
\hline Food, Beverages and Tobacco & 33.4 & 32.8 & 19 & 49 & 11 \\
\hline Textile, Wearing Apparel and Leather & 14.8 & 3.9 & 18 & 52 & 9 \\
\hline Wood and Wood Products & 9.6 & 5.0 & 22 & 59 & 14 \\
\hline Paper, Printing and Publishing & 5.4 & 7.8 & 23 & 56 & 14 \\
\hline Chemical,Petroleum,Coal,Rubber,Plastic & 12.2 & 14.1 & 32 & 57 & 19 \\
\hline Non-Metallic Mineral Products & 4.7 & 4.7 & 15 & 43 & 7 \\
\hline Basic Metal Industries & 1.7 & 23.5 & 44 & 42 & 19 \\
\hline Fabricated Metal Products, M\&E & 16.7 & 8.0 & 19 & 52 & 11 \\
\hline Other Manufacturing Industries & 1.4 & 0.2 & 21 & 48 & 9 \\
\hline Total & 100 & 100 & 21 & 52 & 12 \\
\hline
\end{tabular}

Notes: This table reports the percent of plants, real output, exporters, multiple product plants and multiple product exporting plants by sector. Multiple product plants are those that report production of more than one ENIA defined product in a given year. Exporting plants are those that report the export of at least one product in a given year. Data are for the 1996 to 2003 pooled sample. 